\title{
BOND BETWEEN STEEL AND SELF-COMPACTING CONCRETE IN COMPOSITE TUBE COLUMNS
}

\author{
M. SZADKOWSKA ${ }^{1}$, E. SZMIGIERA ${ }^{2}$
}

\begin{abstract}
This paper presents research results of composite tubes filled with self-compacting concrete. The impact of the selected materials and geometric factors on resistance to the vertical shear was evaluated in this study. The resistance of the tested members was compared with recommendations given in Eurocode PN-EN 1994-1-1. From the results obtained in the tests it can be deduced that more parameters should be taken into consideration when determining resistance to the vertical shear in the interface between steel and concrete than PN-EN 19941-1 recommends.
\end{abstract}

Keywords: composite, self-compacting, concrete, vertical shear resistance, bond, tubes

\section{INTRODUCTION}

The bond between steel and concrete in compressed composite columns in certain specific situations plays an important role in the performance of these members. Such situations occur, for example, when a column is loaded with additional transverse force applied to the outside of the support area, or when the compressive force is eccentricity applied. These types of loads may cause big bending moments, which change the nature of work from a composite column into a composite beam. Engineering practices indicate that applying a load to the entire cross-section is not possible in every situation. Therefore, in these cases, the bond between steel and concrete will be also very significant. In existing literature, there are a small number of publications concerning the issue of bond strength between steel and concrete in composite compressed elements. Among them,

\footnotetext{
${ }^{1}$ MSc., Eng. Magdalena Szadkowska, Warsaw University of Technology, Faculty of Civil Engineering, Al. Armii Ludowej 16, 00-637 Warsaw, Poland, e-mail: m.szadkowska@il.pw.edu.pl

${ }^{2}$ DSc., PhD., Eng. Elżbieta Szmigiera, Warsaw University of Technology, Faculty of Civil Engineering, Al. Armii Ludowej 16, 00-637 Warsaw, Poland, e-mail: e.szmigiera@il.pw.edu.pl
} 
positions [8] and [9] by K. S Virdi and P. J. Dowling are significant. In these papers, the scientists presented the test results of the bond strength in steel tubes filled with concrete. They were analysing vertical shear resistance according to the selected parameters; such as contact surface, age, and compressive strengths of concrete. As it can be seen in research described by Virdi and Dowling, the contact surface does not have a significant influence on the resistance to vertical shear between the steel tube and the concrete filling. Moreover, using concrete of a higher grade, characterised by higher shrinkage, reduces the beneficial effect of the interlocking of both materials. According to the authors, the age of the concrete influences bond strength between steel and concrete. It needs to be mentioned here that tests were carried out after 7, 21, and 28 days postconcrete fill. Y. M. Hunaiti has come to slightly different conclusions and presented in [1] and [2] the results of the research and analysis of bond conditions in selected types of two-chord composite columns. Members tested by Y. M. Hunaiti were $300 \mathrm{~mm}$ in height and consisted of two C channels filled with concrete. Transverse dimensions of the cross-section changed depending on the adopted types of $\mathrm{C}$ channels and the space between them. Moreover, the changing parameters were the grade of concrete and the time at which the tests were carried out. An important conclusion of these papers is that the bond between steel and concrete largely depends on the type of composite crosssection. Furthermore, the age of concrete largely influences bond conditions, as vertical shear resistance for members tested after 360 days was around $30 \%$ of the value obtained after 21 days post-fill (with concrete). The investigation of the bond in steel tubes filled with normal concrete was the subject of research made by Roeder, Cameron, and Brown in [5]. In their opinion, due to the phenomenon of shrinkage, bond strengths in concrete in tested members decrease with the increase of the tube diameter or with the increase of the diameter-to-thickness ratio. In known literature on the subject there are also papers concerning the impact of concrete mixture types on the bond strength between steel and concrete. Moulia M. and Khelafi H. in [4] analysed the impact of lightweight aggregate concrete (LWAC) against values of bond strength. Their tests indicated better composite action in members filled with (LWAC) than with those filled with normal concrete. In 2003, Li G., Zhao X., and Chen L. published in [3] the results of steel tubes filled with normal concrete with an added expansive agent. The authors proved in their paper that the bond strength was enhanced significantly during the first 7 days of concrete curing. After that time, between 7 and 28 days, the strength gain slowed. The research results of the bond between steel and concrete in composite columns whose cross-sections consisted of two steel double-I sections HEA 160 filled with concrete were presented by E. Szmigiera and P. Woyciechowski in [6] and in [7] by E. 
Szmigiera, P. Woyciechowski and M. Szadkowska. From the performed analysis the following conclusions have been reached:

- resistance to vertical shearing increases with the increase of the cylinder compressive strength of self-compacting concrete (SCC),

- vertical shear resistance growth is not proportional to the growth of the cylinder compressive strength in the concrete,

- the total SCC shrinkage negatively affects its bond to steel,

- the use of SCC weakens steel-concrete bonds in comparison with vibrated concrete.

Due to the advantages of using SCC in composite elements associated with the lack of space to compact concrete properly, the authors decided to research bond strengths in steel tubes filled with self-compacting concrete.

\section{RESEARCH OUTLINE}

The research was carried out on thirteen members from which three characteristic types of crosssections can be distinguished Table 1 .

Table 1. Cross section types

\begin{tabular}{|c|c|c|c|c|c|}
\hline $\begin{array}{l}\text { Notation } \\
\text { of series }\end{array}$ & Cross-section types & $\begin{array}{c}\text { Cross-section } \\
\text { dimensions }\end{array}$ & $\begin{array}{l}\text { Type of } \\
\text { filling }\end{array}$ & $\begin{array}{c}\text { Mean value of cylindrical } \\
\text { compressive strength of } \\
\text { concrete } f_{c}[\mathrm{MPa}]\end{array}$ & $\begin{array}{c}\text { Contact } \\
\text { surface } \\
{\left[\mathrm{mm}^{2}\right]}\end{array}$ \\
\hline 1 & 2 & 3 & 4 & 5 & 6 \\
\hline STS & $\begin{array}{c}\text { square hollow } \\
\text { section, thin wall }\end{array}$ & $180 \times 180 \times 6 \mathrm{~mm}$ & \multirow{3}{*}{$\begin{array}{l}\text { stronger } \\
\text { SCC }\end{array}$} & \multirow{3}{*}{45.6} & 201600 \\
\hline STHS & $\begin{array}{c}\text { square hollow } \\
\text { section, thicker wall }\end{array}$ & $180 \times 180 \times 10 \mathrm{~mm}$ & & & 192000 \\
\hline CS & $\begin{array}{l}\text { circular hollow } \\
\text { section, thin wall }\end{array}$ & \multirow{2}{*}{$\begin{array}{c}\text { diameter } \mathrm{D}=219.1 \mathrm{~mm} \text {, } \\
\text { thickness of the profile } \\
\text { wall } \mathrm{t}=6 \mathrm{~mm}\end{array}$} & & & \multirow{2}{*}{195187} \\
\hline CW & $\begin{array}{l}\text { circular hollow } \\
\text { section, thin wall }\end{array}$ & & $\begin{array}{c}\text { weaker } \\
\text { SCC }\end{array}$ & 35.2 & \\
\hline
\end{tabular}

The cross-sections of the members were chosen in a way so that the areas of the contact surfaces were approximately equal to each other and did not constitute a variable parameter in the research. Variable factors analysed during the tests were:

- concrete grade filling the cross section, 
- thickness of the steel profile wall: $6 \mathrm{~mm}$ or $10 \mathrm{~mm}$ (in the case of square hollow sections),

- type of steel surface: square hollow section or circular hollow section.

The heights of all types of members were $300 \mathrm{~mm}$. The types of cross-sections of the tested members are presented in Fig. 1.

a)

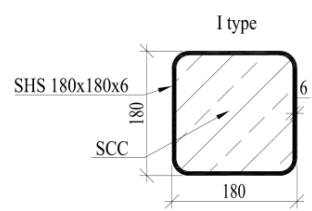

b)

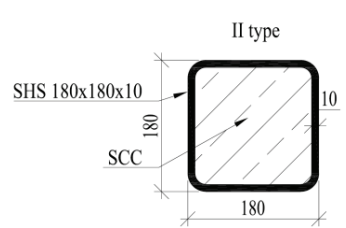

c)

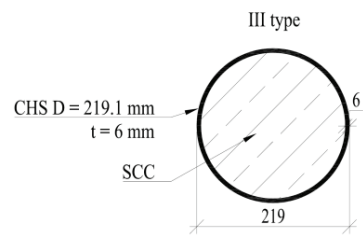

Fig. 1. Cross-sections of the members: a) square hollow section tube with a thin wall - STS, b) square hollow section tube with a thicker wall - STHS, c) circular hollow section tube - CS (stronger SCC) and CW (weaker SCC)

In the first and second type of cross-sections there were three members of each type with the centre filled with SCC with a mean value of cylindrical compressive strength of the concrete set as $f_{c}=45.6 \mathrm{MPa}$. In the case of the third type of cross-section, the centre of the member was filled with SCC of two different concrete grades: $f_{c}=45.6 \mathrm{MPa}-3$ members, $f_{c m}=35.2 \mathrm{MPa}-4$ members. The examination of these members was carried out in the Laboratory of the Institute of Civil Engineering at the Warsaw University of Technology. The specimens were prepared so that the concrete core was front-end above the top surface of the steel profile. Free space was left at the bottom to enable the vertical travel of the concrete core at the moment of braking bond strength. The members were tested in a hydraulic press as shown in Fig. 2b)
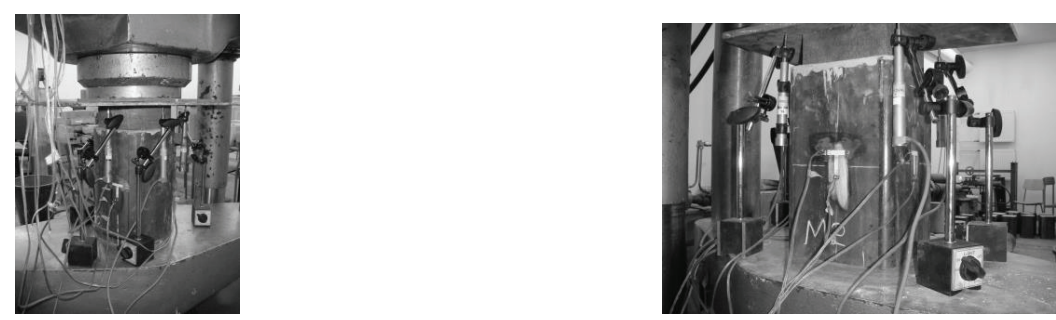

Fig. 2. Test stand: a) circular hollow cross-section members, b) square hollow cross-section members 
The compressive axial force was evenly applied to the entire top surface of the concrete core through a steel plate. The vertical displacement of the concrete core was measured using four inductive sensors placed onto the steel plate. In the middle of each specimen's height, two strain gauges were placed at the steel surface walls. On each wall, longitudinal and transversal strains were measured. In order to determine the mechanical characteristics of the concrete, cubic samples with side dimensions of $150 \mathrm{~mm}$ - for testing compression and tensile strength - were made.

\section{ANALYSIS OF TESTS RESULTS}

\subsection{DiSPLACEMENTS OF CONCRETE}

Through analysing the concrete displacement diagrams it is still difficult to determine a specific force value at which the loss of the bond between steel and concrete takes place. Therefore, a contractual value of force at which, according to the authors, the loss of bond began, is assumed for each case. These are values at which the acceleration of displacements growth is visible on the concrete displacements diagrams, while on the steel profile strains diagram the decline of transversal strains can be seen. Diagrams of concrete displacements and transversal strains of steel surface of members STS and STHS are presented in Fig. 3. Diagrams of concrete displacements of square hollow section tubes with thin walls have a slightly different course than tubes with a thicker wall. Diagrams based on tests of STS members have an almost linear character, until bond strength between steel and concrete is lost. When analysing the concrete displacements diagram of STHS members, a curvilinear character can be observed. Although it should be noted that in a load range of $0 \mathrm{kN}$ to about $50 \mathrm{kN}$ (in both) cases the curves have an almost linear character. However, members with thicker steel walls obtain greater force values at which bond strength is lost, equal to about $167.7 \mathrm{kN}$. When the bond is lost, in members of the STS type, and the moment did not come at a force of $51.8 \mathrm{kN}$, perhaps the concrete displacement diagram would have the same shape as the STHS members. The greater force value at which the slip comes in specimens of STHS type is the result of an increase in concrete compressive strength caused by the confinement phenomenon. This phenomenon progresses with the growth of the thickness and stiffness of the steel profile wall. The results of the research suggest that concrete compressive strength has an impact on its bond to the steel profile. Differences in curve shapes are also visible on diagrams of circular hollow section tubes in Fig. 4. Parallels between the curves on the concrete displacement diagram of the CS members (filled with stronger SCC) and the STHS ones can be seen there. At the same time, we 
observe that in both the STS and CS specimens, the geometry of the cross-section affects the force values at which the slip comes.

a)

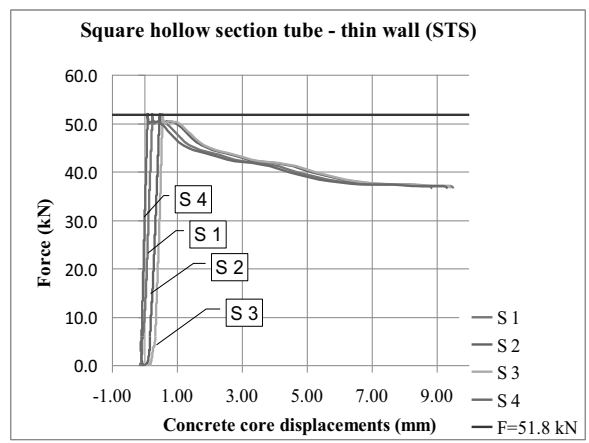

c)

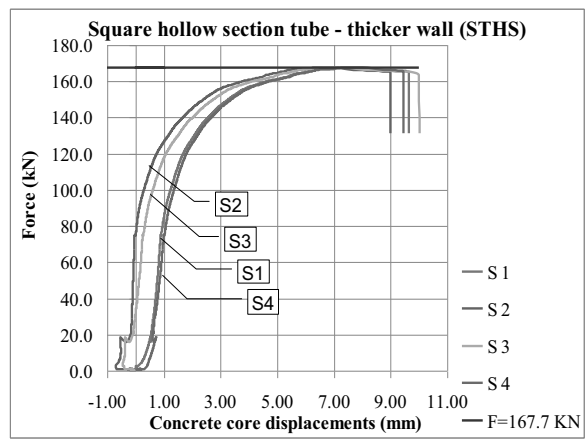

b)

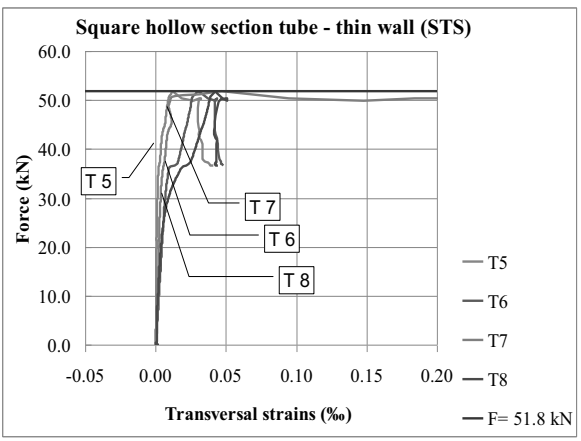

d)

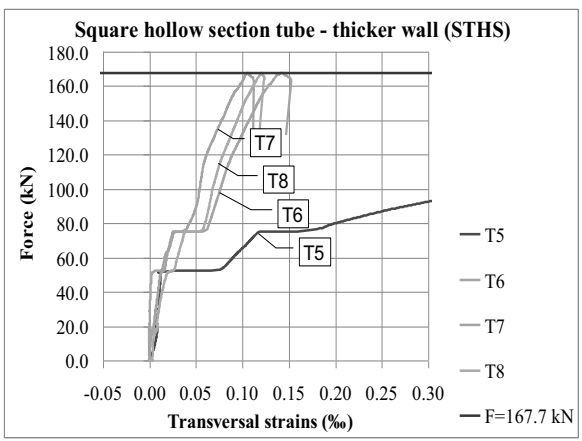

Fig. 3. Diagrams of concrete core displacements and steel surface transversal strains: square hollow section tube with thin wall - STS: a) concrete displacements, b) steel surface transversal strains; square hollow section tube with a thicker wall - STHS: c) concrete displacements, d) steel surface transversal strains

It should be mentioned that both types of specimens were filled with concrete of the same grade and both had the same steel profile wall thickness. The force value at which bond strength is lost is greater in CS members than in STS members by about $24.5 \%$. It is also important to note the force value at which the slip of concrete takes place in specimens CW and STHS. Although members of the square hollow section had thicker steel profile walls ( by $4 \mathrm{~mm}$ ) and were filled with concrete of a higher grade than the CW members. They attained nearly the same value of force at which the bond strength between the steel and the concrete was lost, when compared to members with a 
circular hollow section filled with weaker concrete. The above observations confirm the impact of concrete grade and the confinement phenomenon on the increase of force at which the bond between steel and concrete is lost.

a)

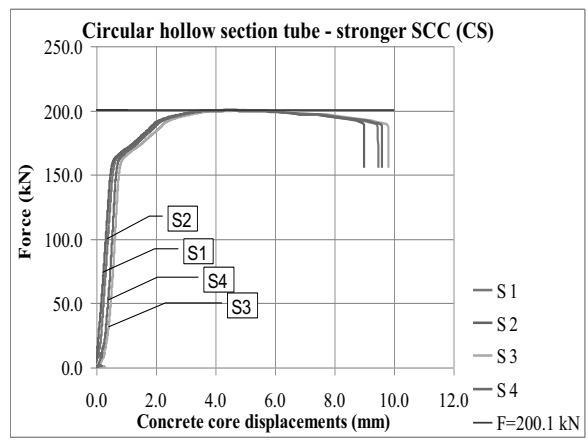

c)

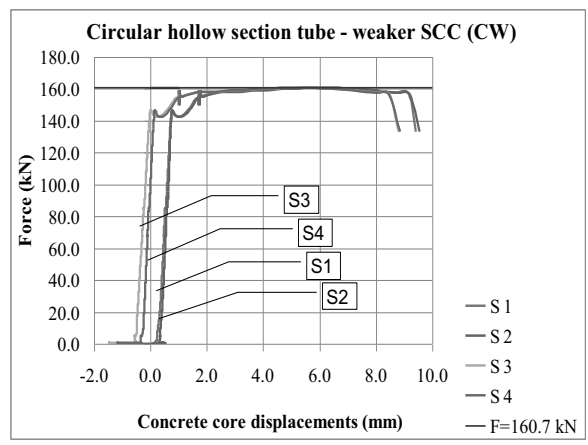

b)

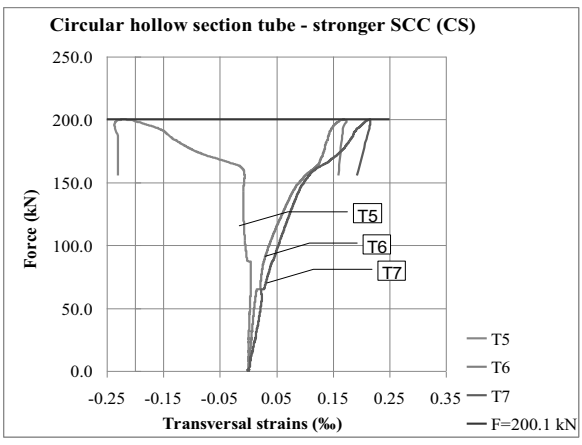

d)

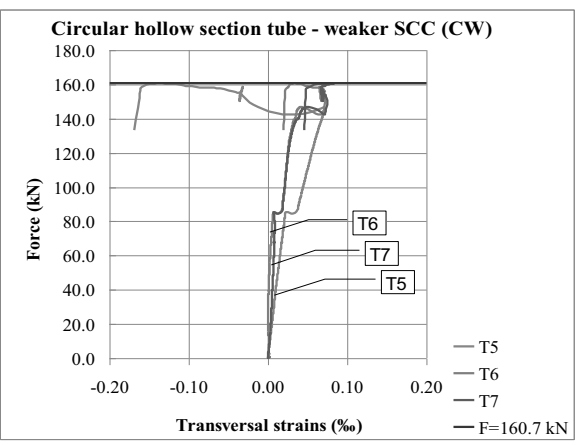

Fig. 4. Diagrams of concrete core displacements and steel surface transversal strains: circular hollow section tube, stronger SCC - CS: a) concrete displacements, b) steel surface transversal strains; circular hollow section tube, weaker SCC - CW: c) concrete displacements, d) steel surface transversal strains

\subsection{RESISTANCE TO VERTICAL SHEAR IN THE INTERFACE BETWEEN STEEL AND CONCRETE}

Analysis of resistance to vertical shear was compared with recommendations given in PN-EN 19941-1 in the chapter entitled "Shear connection and load introduction". It should be noted that the recommendations included in this standard concern members made of normal concrete, while the analysed specimens were made of self-compacting concrete. In accordance with the resolutions 
included in [10], in regions of load introduction and when loads occur locally within the length and moments applied for members connected to the ends, the distribution of shear resistance at the interface between steel and concrete shall be applied. This implies that in each mentioned case shear stresses at the interface between steel and concrete should be recorded and compared against the referential value of design shear strengths from Table 2 . If shear stresses are greater than $\tau_{\mathrm{Rd}}$, the shear connectors providing appropriate shear connection at the interface between steel and concrete should be applied.

Table 2. Design shear strengths $\tau_{\text {Rd }}$ by [10]

\begin{tabular}{|c|c|}
\hline Type of cross section & $\tau_{\mathbf{R d}}\left[\mathbf{N} / \mathbf{m m}^{\mathbf{2}}\right]$ \\
\hline Completely concrete encased steel sections & 0.30 \\
Concrete filled circular hollow sections & 0.55 \\
Concrete filled rectangular hollow sections & 0.40 \\
Flanges of partially encased sections & 0.20 \\
Webs of partially encased sections & 0 \\
\hline
\end{tabular}

In Table 2 of standard [10], design shear strengths in composite steel and concrete columns depend solely on the type of cross-section; however, the data does not include other parameters, such as concrete grade or cross-section dimensions. From information available from literature as well as from the conducted research, it stands to reason that this is not a fully correct approach. Table 3 presents the results of mean shear stresses obtained for circular and square hollow section tubes. In column 4 values of mean shear stresses $\tau_{\mathrm{m}}$ are presented, having been obtained from dividing the mean force breaking the bond strengths by the contact area. It should be noted that the values of the contact area of every type of cross-section are approximately equal to each other (Table 1, column 6). In column 5, design mean values of shear stresses obtained by dividing the mean shear stresses by the partial factor $\gamma_{\mathrm{vs}}=1.25$ were determined. The standard values of design shear strengths $\tau_{\mathrm{Rd}}$ for each type of cross-section using normal concrete are presented in column 6. Column 7 gives values of the ultimate relative bond in relation to concrete compressive strength $\tau_{\mathrm{m}} / \mathrm{f}_{\mathrm{c}}$. Comparing $\tau_{\mathrm{md}}$ values determined for square hollow section tubes STS and STHS in Table 3, we see that the thickness of the steel surface influences shear stress values. Stresses $\tau_{\mathrm{md}}$ obtained by the STS specimens are equal to $0.24 \mathrm{~N} / \mathrm{mm}^{2}$, which is about $34 \%$ of those achieved by the STHS tubes. Important in these calculations is the fact that the thickness of the steel walls of the STHS members is $40 \%$ greater than STS. With circular hollow section tubes CS and CW, the only variable 
parameter was the grade of concrete filling the centres of the tubes. A higher grade of concrete in the CS specimens affected the increase of mean shear stresses.

Table 3. Comparison of mean shear stresses with $\tau_{\mathrm{Rd}}$

\begin{tabular}{|c|c|c|c|c|c|c|}
\hline \multirow[b]{2}{*}{$\begin{array}{l}\text { Notation } \\
\text { of series }\end{array}$} & \multirow{2}{*}{$\begin{array}{c}\text { Mean value of } \\
\text { cylindrical } \\
\text { compressive } \\
\text { strength of } \\
\text { concrete } \\
\text { f }_{c} \text { (SCC) } \\
\text { [MPa] }\end{array}$} & \multirow{2}{*}{$\begin{array}{c}\text { Mean force } \\
\text { breaking the } \\
\text { bond strengths } \\
{\left[10^{3} \mathrm{~N}\right]}\end{array}$} & \multicolumn{2}{|c|}{$\begin{array}{c}\text { Mean shear stresses } \\
{\left[\mathbf{N} / \mathbf{m m}^{2}\right]}\end{array}$} & \multirow{2}{*}{$\begin{array}{c}\text { Design shear strength } \\
\tau_{\mathrm{Rd}}\left[\mathrm{N} / \mathrm{mm}^{2}\right] \text { - values } \\
\text { acc. } \mathrm{PN}-\mathrm{EN} \text { 1994-1-1 } \\
\text { (normal concrete) }\end{array}$} & \multirow[b]{2}{*}{$\tau_{\mathrm{m}} / \mathbf{f}_{\mathrm{c}}$} \\
\hline & & & $\tau_{\mathrm{m}}$ & $\tau_{\mathrm{md}}=\tau_{\mathrm{m}} / \gamma_{\mathrm{vs}}$ & & \\
\hline 1 & 2 & 3 & 4 & 5 & 6 & 7 \\
\hline STS & \multirow{3}{*}{45.6} & 61000 & 0.30 & 0.24 & \multirow{2}{*}{0.40} & 0.005 \\
\hline STHS & & 171000 & 0.89 & 0.71 & & 0.016 \\
\hline $\mathrm{CS}$ & & 196400 & 1.01 & 0.81 & \multirow{2}{*}{0.55} & 0.018 \\
\hline $\mathrm{CW}$ & 35.2 & 151275 & 0.78 & 0.62 & & 0.018 \\
\hline
\end{tabular}

Analysing the results obtained from the test for both the STHS and CS members, it can be seen that the STHS specimens achieved a lower value of shear stresses by about $11 \%$, despite having a $40 \%$ thicker wall. From the analysis of the values of the ultimate relative bonds, it can be concluded that the geometry of the cross-section dimensions has a greater impact on bond strength than concrete grade. The results obtained from the research of the design mean shear stresses $\tau_{\mathrm{md}}$ are different than the design shear strengths $\tau_{R d}$ found in Table 2 of standard [10]. Considering tubes of square hollow sections, it can be noted that the thickness of the steel profile wall has a significant impact on mean shear stresses values. In the case of the circular hollow section tubes in which the only variable factor was concrete grade, some differences in the calculated values of mean shear stresses were also present.

\section{Conclusions}

In this analysis the impact of the selected materials and geometric factors on resistance to the vertical shear in composite tube members filled with self-compacting concrete was assessed. From the results obtained from testing, the following conclusions can be drawn:

- The resistance of shear connections is affected by: the thickness of the steel profile wall, the geometry of the cross-section, and the concrete grade. 
- The diagrams of concrete core displacements of square hollow section tubes present slightly differently in members with thin walls than in those with thicker walls. Diagrams based on tests of the STS members have an almost linear character, while graphs of the STHS members have a curvilinear shape.

- The thickness of the steel's surface does have an impact on mean shear stresses values $\tau_{\mathrm{md}}$ in the square hollow section tubes. Members with thin walls (STS) reached a lower value of $\tau_{\mathrm{md}}$ stresses than the tubes with thicker walls (STHS). This increase of $\tau_{\mathrm{md}}$ stresses in STHS members is caused by concrete's confinement phenomenon.

- In the case of circular hollow section tubes, higher grades of concrete caused an increase in mean shear stresses.

- The mean shear stresses achieved by the circular hollow section tubes are greater than the shear stresses obtained by the square hollow section members, despite the fact that they were filled with concrete of the same grade. This may lead to the conclusion that the geometry of the crosssection has a greater impact on the value of $\tau_{\mathrm{md}}$ than the thickness of the tube's wall.

As we deduce from the above research results, cross-section types should not be the sole factor taken into consideration when determining resistance to vertical shear in the interface between steel and concrete, as per recommendations of Eurocode 2.

\section{REFERENCES}

1. Hunaiti Y. M., "Bond strength in battened composite columns", Journal of Structural Engineering 117(3): pp. 699-714, 1991.

2. Hunaiti Y. M., "Aging effect on bond strength in composite sections", Journal of Materials in Civil Engineering 6(4): 469-73, 1994.

3. Li G., Zhao X., Chen L., "Improve the strength of concrete-filled steel tubular columns by the use of fly ash", Cement and Concrete Research 33 (5): pp. 733-739, 2003.

4. Moulia M., Khelafi H., "Strength of short composite rectangular hollow section columns filled with lightweight aggregate concrete”, Engineering Structures 29: pp. 1791-1797, 2007.

5. Roeder C. W., Cameron B., Brown C. B., "Composite action in concrete filled tubes", Journal of Structural Engineering 125(5): pp. 477-484, 1999.

6. Szmigiera E., Woyciechowski P., "Influence of the compaction method on the bond between steel and concrete in composite columns”, Periodica Polytechnica-Civil Engineering vol. 57, nr 2, pp. 129-137, 2013.

7. Szmigiera E., Woyciechowski P., Szadkowska M., „Badania przyczepności betonu do stali konstrukcyjnej w słupach zespolonych", Beton i Konstrukcje z betonu-badania Seria Monografie Zakładu Konstrukcji Betonowych i Zakładu Inżynierii Materiałów Budowlanych, rozdz. 9, pp. 111-127, 2015.

8. Virdi K. S., Dowling P. J., "Bond strength in concrete filled circular steel tubes", CESLIC Report CC11, Department of Civil Engineering, Imperial College, London, 1975, December.

9. Virdi K. S., Dowling P. J., "Bond strength in concrete filled steel tubes", IABSE proceedings = Memoires AIPC IVBH Abhandlungen, 1980.

10. PN-EN 1994-1-1-2008 - Design of composite steel and concrete structures Part 1-1: General rules and rules for buildings. 


\section{LIST OF FIGURES AND TABLES:}

Fig. 1. Cross-sections of the members: a) square hollow section tube with a thin wall -STS, b) square hollow section tube with a thicker wall - STHS, c) circular hollow section tube - CS (stronger SCC) and CW (weaker SCC)

Rys. 1. Przekroje próbek: a) rura kwadratowa z cienką ścianką - STS, b) rura kwadratowa z grubą ścianką STHS, c) rura o przekroju kołowym - CS (beton mocniejszy) i CW (beton słabszy)

Fig. 2 Test stand: a) circular hollow cross-section members, b) square hollow cross-section members Rys. 2. Stanowisko badawcze: a) próbki o przekroju kołowym, b) próbki o przekroju kwadratowym Fig. 3. Diagrams of concrete core displacements and steel surface transversal strains: square hollow section tube with thin wall - STS: a) concrete displacements, b) steel surface transversal strains; square hollow section tube with the thicker wall - STHS: c) concrete displacements, d) steel surface transversal strains Rys. 3. Wykresy przemieszczeń rdzenia betonowego i odkształceń poziomych płaszcza stalowego: rura kwadratowa ścianka cienka - STS: a) przemieszczenia betonu, b) odkształcenia poziome stali; rura kwadratowa ścianka gruba - STHS: c) przemieszczenia betonu, d) odkształcenia poziome stali

Fig. 4. Diagrams of concrete core displacements and steel surface transversal strains: circular hollow section tube, stronger SCC - CS: a) concrete displacements, b) steel surface transversal strains; circular hollow section tube, weaker SCC - CW: c) concrete displacements, d) steel surface transversal strains Rys. 4. Wykresy przemieszczeń rdzenia betonowego i odkształceń poziomych płaszcza stalowego: rura okrągła, beton mocny- CS: a) przemieszczenia betonu, b) odkształcenia poziome stali; rura okrągła, beton słaby - CW: c) przemieszczenia betonu, d) odkształcenia poziome stali

\section{Tab. 1. Cross-section types}

Tab. 1. Rodzaje przekrojów

Tab. 2. Design shear strengths $\tau_{\text {Rd }}$ by [10]

Tab. 2. Obliczeniowa nośność na ścinanie $\tau_{\text {Rd }}$ według [10]

Tab. 3. Comparison of mean shear stresses with $\tau_{R d}$

Tab. 3. Porównanie wartości średnich naprężeń ścinających z wartością $\tau_{\mathrm{Rd}}$ 


\section{PRZYCZEPNOŚĆ MIĘDZY STALĄ I BETONEM SAMOZAGĘSZCZALNYM W ZESPOLONYCH SEUPACH O PRZEKROJU RUROWYM}

Slowa kluczowe: zespolenie, beton samozagęszczalny, nośność na ścinanie, przyczepność, rury

\section{STRESZCZENIE:}

W niniejszym artykule przedstawiono wyniki badań przyczepności między stalą i betonem samozagęszczalnym $\mathrm{w}$ zespolonych elementach o przekroju rurowym. Badania przeprowadzono na trzynastu próbkach, z których można wydzielić trzy charakterystyczne typy przekrojów Rys. 1.

a)

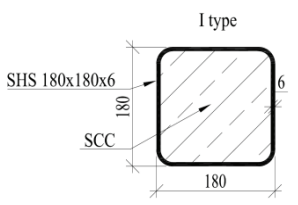

b)

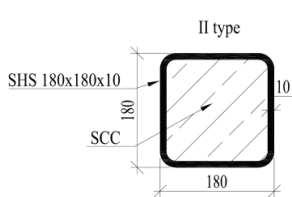

c)

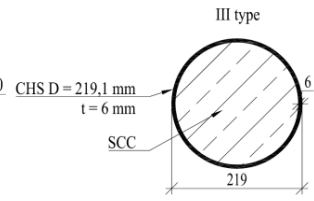

Rys. 1. Przekroje próbek: a) rura kwadratowa z cienką ścianką - STS, b) rura kwadratowa z grubą ścianką - STHS, c) rura o przekroju kołowym - CS (beton mocniejszy) i CW (beton słabszy).

Przekroje próbek zostały tak dobrane, aby powierzchnie zespolenia były w przybliżeniu równe i nie stanowiły parametru zmiennego w badaniach. Parametrami zmiennymi, analizowanymi w trakcie badań, były:

- klasa wytrzymałości betonu wypełniającego przekrój

- grubość ścianki profilu stalowego: $6 \mathrm{~mm}$ lub $10 \mathrm{~mm}$ w przypadku rury kwadratowej

- rodzaj płaszcza stalowego: rura kwadratowa lub rura okrągła

Wysokość wszystkich próbek wynosiła $300 \mathrm{~mm}$. Badania polegały na przyłożeniu osiowej siły podłużnej do wystającej w górnej części powierzchni rdzenia betonowego i wpychaniu go do środka. W celu przeniesienia podłużnych naprężeń stycznych tylko za pomocą naprężeń przyczepności na dole próbki pozostawiono pustkę powietrzną. W trakcie badań dokonywano pomiarów przemieszczeń rdzenia betonowego oraz odkształceń podłużnych i poprzecznych płaszcza stalowego za pomocą tensometrów elektrooporowych, które umieszczone były w środku wysokości próbek.

Analiza wyników badań polegała m.in. na porównaniu nośności na ścinanie badanych elementów z zaleceniami podanymi w normie PN-EN 1994-1-1, rozdział zatytułowany „Zespolenie i przekazywanie obciążeń”. Należy zaznaczyć, że zawarte w normie zalecenia dotyczą elementów wykonanych z betonu zwykłego, natomiast próbki będące przedmiotem niniejszej analizy zostały wykonane $\mathrm{z}$ betonu SCC. Zgodnie z wytycznymi zawartymi w wymienionej powyżej normie należy wyznaczyć naprężenia ścinające na styku stali i betonu i porównać je z wartością referencyjną obliczeniowej nośności na ścinanie podaną w normie. Jeżeli naprężenia ścinające są większe od wartości $\tau_{\mathrm{Rd}}$ należy zastosować odpowiednie łączniki, które zapewnią właściwe zespolenie na styku beton - stal. W normie obliczeniową nośność na ścinanie zespolonych słupów stalowo - betonowych uzależniono jedynie od rodzaju przekroju, natomiast nie uwzględniono innych parametrów, takich jak klasa wytrzymałości betonu, czy wymiary poprzeczne przekroju. $\mathrm{Z}$ informacji dostępnych w literaturze, a także z przeprowadzonych badań wynika, że nie jest to do końca właściwe podejście. 
W powyższej analizie rozważano wpływ wybranych parametrów materiałowych i geometrycznych na nośność zespolenia w elementach o przekrojach rurowych wypełnionych betonem SCC. Z otrzymanych wyników można wysnuć następujące wnioski:

- Przy określaniu nośności zespolenia należy wziąć pod uwagę takie parametry, jak: grubość ścianki profilu stalowego, wytrzymałość betonu na ściskanie, geometria przekroju.

- Wykresy przemieszczeń betonowego rdzenia uzyskane z badań próbek o przekroju kwadratowym, wykazują inny charakter w zależności od grubości płaszcza stalowego. Wykresy uzyskane z badań próbek typu STS mają charakter prawie liniowy, natomiast w przypadku próbek STHS wykres jest bardziej zakrzywiony.

- Grubość płaszcza stalowego wpływa na średnią wartość naprężeń ścinających $\tau_{\mathrm{m}} \mathrm{w}$ przypadku rur o przekroju kwadratowym. Próbki z cienką ścianką (STS) uzyskały niższe wartości naprężeń $\tau_{\mathrm{md}}$, niż próbki z grubszą ścianką (STHS). Wzrost wartości podłużnych naprężeń ścinających wywołany jest zjawiskiem skrępowania betonu.

- W przypadku rur o przekroju kołowym, w próbkach wypełnionych wyższą klasą betonu, uzyskano wyższe wartości naprężeń ścinających, niż w próbkach wypełnionych słabszym betonem.

- Średnie wartości naprężeń ścinających uzyskane przez próbki o przekroju kołowym są wyższe niż w przypadku próbek o przekroju kwadratowym, pomimo tego, że zostały wypełnione betonem tej samej klasy wytrzymałości.

Można w związku z tym wysnuć wniosek, że geometria przekroju miała większy wpływa na wartość naprężeń $\tau_{\mathrm{md}}$ niż grubość ścianki płaszcza stalowego.

Podsumowując przeprowadzone analizy można stwierdzić, że przy określaniu nośności na ścinanie w miejscu zespolenia betonu z profilem stalowym, należy wziąć pod uwagę nie tylko typ przekroju, ale również jego geometrię, grubość płaszcza profilu stalowego oraz klasę wytrzymałości betonu na ściskanie. 